\title{
PENGARUH PEMBELAJARAN PENGAJUAN MASALAH BERBANTUAN GEOGEBRA TERHADAP PEMAHAMAN KONSEP MATEMATIKA, BERPIKIR KRITIS, DAN PENALARAN ADAPTIF SISWA
}

\author{
Evan Bagus Armanda Putra \\ Program Studi Pendidikan Matematika, Fakultas Matematika dan Ilmu Pengetahuan Alam, Universitas Negeri Surabaya \\ Email: evanputra@mhs.unesa.ac.id \\ Tatag Yuli Eko Siswono \\ Program Studi Pendidikan Matematika, Fakultas Matematika dan Ilmu Pengetahuan Alam, Universitas Negeri Surabaya \\ Email: tatagsiswono@unesa.ac.id
}

\begin{abstract}
Abstrak
Penelitian ini bertujuann untuk mengetahui pengaruh pembelajaran pengajuann masalah berbantuan GeoGebra yang digunakan terhadap pemahaman konsep, berpikir kritis, dan penalaran adaptif pada siswa. Penelitian ini dilakukan pada pokok bahasan, transformasi geometri yaitu pada materi translasi, refleksi, rotasi, dan dilatasi untuk siswa kelas XI IPA 1 SMA Amanatul Ummah Surabaya. Penelitian ini menggunakan metode Pre-Experimental Design dengan jenis rancangan One Group Pretest-Posttest Design. Sampel penelitian berjumlah 25 siswa dan diberi perlakuan berupa pembelajaran pengajuan masalah berbantuan GeoGebra dengan diberikannya Pretest dan Posttest pada pembelajaran sebelum menggunakan GeoGebra dan setelah menggunakan GeoGebra. Lembar Pretest dan Posttest, lembar observasi aktifitas siswa, dan angket respon siswa digunakan sebagai instrumen dalam penelitian ini. Berdasarkan uji Wilcoxon menunjukkan adanya pengaruh yang signifikan pada hasil penelitian ini yang berupa peningkatan pada kemampuan pemahaman konsep, berpikir kritis, dan penalaran adaptif siswa karena diperoleh $\mathrm{N}$-gain pemahaman konsep 0.18 , berpikir kritis 0.10 , dan penalaran adaptif 0.08 yang tergolong rendah. Hasil uji normalitas data diperoleh signifikansi pemahaman konsep 0.008, berpikir kritis 0.009 , dan penalaran adaptif 0.001 dengan seluruh data bernilai $<0.05$, makadata tidak berdistribusi normal sehingga dilakukan uji non parametrik Kruskal-Wallis. Dari uji non parametrik Kruskal-Wallis menunjukkan hasil nilai Asymp.Sig. 0.068 dan $0.068>0,05$. Hal ini menunjukkan tidak adanya perbedaan peningkatan antara pemahaman konsep, berpikir kritis, dan penalaran adaptif siswa setelah diberikan perlakuan berupa pembelajaran pengajuan masalah berbantuan GeoGebra yang signifikan. Hasil observasi aktivitas siswa menunjukkan menunjukkan aktivitas siswa yang aktif selama pelaksanaan pembelajaran pengajuan masalah berbantuan GeoGebra. Hasil angket respon siswa menunjukkan respon yang positif terhadap pembelajaran pengajuan masalah berbantuan GeoGebra dari semua aspek.
\end{abstract}

Kata Kunci: Pembelajaran Pengajuan Masalah, Pemahaman Konsep, Berpikir Kritis, Penalaran Adaptif, GeoGebra.

\begin{abstract}
This study aims to determine the effect of GeoGebra-assisted problem posing learning that is used on concept understanding, critical thinking, and adaptive reasoning in students. This research was conducted on the subject, geometric transformation, namely the material of translation, reflection, rotation, and dilation for class XI IPA 1 Amanatul Ummah Surabaya students. This study used themethod Pre- Experimental Design with the one group pretest-posttest design type. The research sample consisted of 25 students and were given treatment in the form of learning problemassisted by GeoGebra by giving pretest and posingposttest in learning before using GeoGebra and after using GeoGebra. Sheets pretest and posttest,student activity observation sheet, and a student questionnaire responses are used as an instrument in this study. Based on the Wilcoxon test, it shows that there is a significant effect on the results of this study in the form of an increase in students' concept understanding, critical thinking, and adaptive reasoning abilities because the N-gain of concept understanding is 0.18 , critical thinking is 0.10 , and adaptive reasoning is 0.08 which are classified as low. The results of the data normality test obtained a significance understanding of the concept of $0.008,0.009$ of critical thinking, and 0.001 of adaptive reasoning, with all data valued at $<0.05$, the data were not normally distributed so thenon-parametric KruskalWallistest was performed. From the non-parametric Kruskal-Wallis test, the Asymp.Sig. 0.068 and 0.068>0.05. This shows that there is no significant difference between understanding concepts, critical thinking, and students' adaptive reasoning after being given treatment in the form of GeoGebra-assisted problem posing learning. The results of observations of student activities showed that student activity was active during the implementation of learning problem-posing assisted by GeoGebra. The results of the student response questionnaire showed a positive response to GeoGebra-assisted problem posing learning from all aspects.
\end{abstract}

Keywords: Learning Problem Posing, Concept Understanding, Critical Thinking, Adaptive Reasoning, GeoGebra 


\section{PENDAHULUAN}

Matematika adalah ilmu yang penting, baik pada pendidikan maupun kehidupan sehari-hari, hal ini terbukti dimana di setiap satuan pendidikan pasti diajarkan matematika. Selain itu matematika juga banyak diterapkan di kehidupan sehari-hari dimana matematika dapat membantu manusia untuk menyelesaikan masalah di kehidupan sehari-hari seiring dengan berkembangnya teknologi.

Di Indonesia kemampuan berpikir kritis dan pemahaman konsep matematika masih dibawah rata-rata jika dibandingkan dengan negara lain. Hal itu terbukti dari studi PISA dilakukan pada siswa di berbagai negara. Untuk membantu meningkatkan kemampuan berpikir kritis dan pemahan konsep matematika pada siswa khususnya.

Kemampuan pemahaman konsep matematika dapat dilihat melalui berbagai pendekatan pembelajaran matematika seperti pendekatan pembelajaran matematika realistik dan pembelajaran pengajuan masalah. (Iriyanti, Reni 2017). Pada penelitian ini penulis akan menggunakan pendekatan pembelajaran pengajuan masalah untuk diberikan kepada siswa.

Pembelajaran pengajuan masalah adalah suatu pendekatan pembelajaran dengan merumuskan ulang masalah yang telah diberikan dengan beberapa cara dalam rangka menyelesaikan masalah yang rumit. Dengan pembelajaran ini, siswa akan dituntut untuk berpikir kritis terhadap suatu masalah yang diberikan untuk dirumuskan ulang dimana berpikir kiritis sendiri adalah aktivitas mental yang dilakukan secara sistematis dalam mengelola semua informasi logis atau masalah yang diperoleh untuk menganalisa ide, sehingga dapat membuat keputusan yang tepat untuk menyelesaikan masalah yang dihadapi. Selain itu berpikir kritis juga dideskripsikan sebagai kemampuan untuk menganalisis fakta yang ada kemudian membuat perbandingan. Dengan membuat beberapa perbandingan yang kemudian bisa ditarik kesimpulan dan membuat solusi atas maslah yang ada (Chance, 1986).

Dengan melatih siswa untuk berpikir kritis, siswa diharapkan akan lebih memahami konsep matematika yang diajarkan, karena pemahaman konsep matematika sangat penting sebagai dasar untuk menguasai matematika, hal tersebut di jelaskan pada pernyataan Depdiknas (2006) yang menyatakan bahwa Pemahaman konsep matematika merupakan salah satu kecakapan atau kemahiran matematika yang diharapkan dapat tercapai dalam belajar matematika yaitu dengan menunjukkan pemahan konsep matematika yang dipelajarinya, menjelaskan keterkaitan antar konsep dan mengaplikasikan konsep dan mengaplikasikan konsep atau alogoritma secara luwes, akurat, efisien, dan tepat dalam pemecahan masalah (Kesumawati, 2008:3).
Selain berpikir krtitis, pehaman konsep matematika pada siswa yang matang juga tidak lepas dari penaran adaptif siswa. Penalaran adaptif memiliki komponenkomponen kemahirann matematis siswa dalam belajar matematika. Siswa yang memiliki penalaran adaptif akan berpikir secara logis terhadap materi-materi matematikaa dan dapat menjelaskan serta membuatt pertimbanganpertimbangan terhadap sesuatu yang dikerjakan. Namun seringkali siswa susah untuk mendapat kemampuan itu dikarenakan kurangnya media pembelajaran yang membuat siswa terhambat dalam berpikir kritis dan bernalar sehingga siswa kesulitan untuk memahami konsep, khususnya pada materi geometri dimana visualisasi sangat berpengaruh terhadap pemahaman konsep siswa (Siswono, Tatag Yuli Eko. 2017) Dari hal tersebut salah satu media pembelajaran yang cocok untuk membantu dalam visualisasi guna meningkatkan kemampuan pemahaman konsep, berpikir kritis, dan penalaran adaptif adalah GeoGebra

GeoGebra adalah sebuah aplikasi matematika bersumber terbuka yang dirancang khusus untuk tujuan pendidikan, dan menyatukan geometri, aljabar, kalkulus, bahkan probabilitas dan sumber daya statistik. GeoGebra memungkinkan penggunanya untuk langsung memasukkan dan memanipulasi persamaan dan koordinat, fungsi, menemukan turunan simbolis dan berbagai perintah matematis yang bisa di tampilkan secara visual dengan sudut pandang dua dimensi ataupun tiga dimensi. Dengan aplikasi ini siswa diharapkan lebih mudah untuk memahami beberapa visual yang sulit untuk dideskripsikan sehingga membantu untuk mencapai pehaman konsep matematika dengan baik. Dari hal tersebut penelitian ini bertujuan untuk mengetahui pengaruh pembelajaran pengajuan masalah berbantuan GeoGebra terhadap pemahaman konsep matematika, berpikir kritis, dan penalaran adaptif kemduian dijabakan secara deskriptif.

\section{METODE}

Penelitian ini menggunakan pendekatan kuantitatif. Metode yang digunakan dalam penelitian ini yaitu metode eksperimen dengan bentuk Pre-Experimental Design. Dalam eksperimen pemilihan dilakukan secara acak dari sejumlah populasi yang telah ditentukan yaitu 25 siswa kelas XI IPA 1 SMA Amanatul Ummah Surabaya yang ditenukan secara heterogen dengan perbandingan kemampuan matematika siswa kurang 20\% kurang, 60\% cukup, $20 \%$ baik yang didapat dari tes kemampuan matematika sebelum penelitian. Penelitian ini bertujuann untuk mengetahui pengaruh pembelajaran pengajuann masalah berbantuann GeoGebra terhadap pemahamann konsep matematika, berpikir kritis, dan penalaran adaptif siswa. 
Instrumen yang digunakan dalam penelitian ini yaitu tes kemampuann matematika, soal pre-test, soal post-test, lembar observasi siswa, dan angket respon siswa.

Penelitian ini menggunakan model Pre-Experimental Design dengan bentuk One Group Pre-test-Post-test Design yang berarti bahwa terdapat suatu kelompok diberikan pretest untuk mengetahui kondisi awal kemudian kelompok tersebut diberi perlakuan, diberikan post-test dan selanjutnya diobservasi hasilnya. selanjutnya kondisi awal dibandingkan dengan hasil setelah diberi perlakuan. Dengan desain One Group Pre- test-Post-test Design sebagai berikut :

$$
\begin{array}{ll}
\text { P1 } & \text { X } \\
\text { P1 } \\
\text { X } & \text { : pretest } \\
\text { P2 } & \text { : postlakuan }
\end{array}
$$

Data yang dianalisis menggunakan uji normalitas, uji homogenitas, dan uji N-gain. Jika data tidak berdistribusi normal maka dilakukan uji Wilcoxon Sign Rank dengan hipotesis penelitian sebagai berikut:

$H_{0} \quad=$ Pembelajaran pengajuan masalah berbantuan GeoGebra tidak berpengaruh terhadap kemampuan pemahaman konsep, berpikir kritis, dan penalaran adaptif siswa

$H_{0} \quad=$ Pembelajaran pengajuan masalah berbantuan GeoGebra meningkatkan kemampuan pemahaman konsep, berpikir kritis, dan penalaran adaptif siswa

\section{HASIL DAN PEMBAHASAN}

Penelitian ini bertujuan untuk menjabarkan pengaruh ${ }_{1}$ secara deskriptif tentang pembelajaran pengajuan masalah berbantuan GeoGebra terhadap kemampuan pemahaman konsep, berpikir kritis, dan penalaran adaptif pada siswa kelas XI IPA 1 SMA Amanatul Ummah Surabaya yang berjumlah 25 siswa.

Setelah pembelajaran pengajuan masalah berbantuan GeoGebra, didapat hasil pretest dan posttest siswa. Ratarata hasil pretest dan posttest siswa terdapat pada tabel sebagai berikut :

Tabel 1. Rata-Rata Nilai Pretest dan Posttest

\begin{tabular}{|c|c|c|}
\hline \multirow{2}{*}{ Kemampuan } & \multicolumn{2}{|c|}{ Rata-rata } \\
\cline { 2 - 3 } $\begin{array}{c}\text { Pemahaman } \\
\text { Konsep }\end{array}$ & 20,8 & Posttest \\
\hline Berpikir Kritis & 18,2 & 35,6 \\
\hline $\begin{array}{c}\text { Penalaran } \\
\text { Adaptif }\end{array}$ & 19 & 27,2 \\
\hline
\end{tabular}

Dari Tabel 1 di atas menunjukkan bahwa nilai rata-rat posttest pada pemahaman konsep, berpikir kritis, dan penalaran adaptif $(35.6,27.2,26.2)$ lebih besar dari ratarata nilai pretest $(20.8,18.2,19)$. Untuk melihat adanya pengaruh pembelajaran pengajuan masalah berbantuan GeoGebra pada perbedaan rata-rata nilai tes sebelum diberi perlakuan (pretest) dengan rata-rata nilai tes setelah diberi perlakuan (posttest) dilakukan Uji T-Paired. Karena data tidak berdistribusi normal maka dilakukan uji nonparametrik Wilcoxon Signed Test menggunakan software SPSS. Hasil uji non-parametrik Wilcoxon Signed Test menunjukkan nilai Asymp. Sig > 0.05. Ini menunjukkan bahwa ditolak dan diterima yang berarti terdapat perbedaan yang signifikan antara rata-rata nilai pretest dengan rata-rata nilai posttest. Hal ini menunjukkan bahwa visualisasi sangat membantu siswa dalam tercapainya pemahaman konsep yang baik sehingga siswa lebih mudah memahami dan lebih aktif dalam berpikir secara kritis. Dari hasil ini dapat dinyatakan pembelajaran pengajuan masalah berbantuan GeoGebra berpengaruh terhadap pemahaman konsep, berpikir kritis, penalaran adaptif.

Tabel 2 Data $N$-gain Kemampuan Siswa

\begin{tabular}{|l|l|l|l|l|c|c|}
\hline & \multicolumn{1}{|c|}{$\mathrm{N}$} & Min & \multicolumn{1}{|c|}{ Max } & Mean & SD & V \\
\hline PK & 25 & 0 & .3333 & .1852 & .0721 & 0.005 \\
\hline BK & 25 & 0 & .2222 & .0693 & .0693 & 0.005 \\
\hline PA & 25 & 0 & 6.667 & 1.671 & 2.866 & 8.213 \\
\hline & 25 & & & & & \\
\hline
\end{tabular}

Berdasarkan tabel di atas dapat dilihat bahwa nilai $\mathrm{N}$-gain tertinggi untuk pemahaman konsep adalah 0,33 dan nilai terendahnya adalah 0 , untuk berpikir kritis nilai tertingginya adalah 0,22 dan nilai terendahnya adalah 0 , sedangkan untuk penalaran adaptif nilai tertingginya adalah 6,667 dan terendahnya 0 .

\section{Uji Normalitas $N$-gain}

Uji normalitas bertujuan untuk mengetahui apakah data yang diperoleh berdistribusi normal atau tidak. Uji normalitas dilakukan pada data pretest-posttest nilai kemampuan pemahaman konsep siswa, berpikir kritis, dan penalaran adaptif siswa SPSS. Karena sampel data $<50$ maka uji normalitas yang digunakan adalah uji shapirowilk.

Tabel 3 Hasil Uji Normalitas $\mathbf{N}$-Gain

\begin{tabular}{|l|l|l|l|}
\hline NO & Kelompok & Sig. & Keterangan \\
\hline 1 & PK & 0.008 & Tidak Normal \\
\hline 2 & BK & 0.009 & Tidak Normal \\
\hline 3 & PA & 0.001 & Tidak Normal \\
\hline
\end{tabular}

Berdasarkan pada Tabel 4.5 dapat diketahui hasil uji normalitas menggunakan uji shpairo-wilk yang ditunjukkan dengan nilai signifikansi tiap kelompok. Data dinyatakan normal apabila signifikansi > 0,05. Dari hasil tersebut, diketahui bahwa tidak ada kelompok yang nilai signifikansinya lebih dari 0,05. Dengan demikian, 
disimpulkan bahwa data $\mathrm{N}$-gain secara keseluruhan tidak berdistribusi normal.

\section{Uji Homogenitas}

Tabel 4 Hasil Uji Homogenitas

\begin{tabular}{|l|l|l|}
\hline Kelompok & Sig. & Keterangan \\
\hline N-gain & 0.000 & $\begin{array}{l}\text { Tidak } \\
\text { Homogen }\end{array}$ \\
\hline
\end{tabular}

Berdasarkan pada Tabel 4.6 hasil hitung uji homogenitas $\mathrm{N}$-gain menggunakan uji lavene yang menunjukkan nilai signifikansi $0,000<0,05$, maka dinyatakan sampel $\mathrm{N}$-gain berasal dari populasi yang tidak homogen atau tidak sama.

\section{Uji Hipotesis}

Tabel 5 Hasil Uji Hipotesis

\begin{tabular}{|c|c|c|}
\hline Kelompok & Asymp. Sig. & Keterangan \\
\hline PK_Post- & 0.000 & Berbeda \\
PK_Pre & & secara \\
& & Signifikan \\
\hline BK_Post- & 0.000 & Berbeda \\
BK_Pre & & secara \\
& & Signifikan \\
\hline PA_Post- & 0.000 & Berbeda \\
PA_Pre & & secara \\
& & Signifikan \\
\hline
\end{tabular}

Uji Hipotesis penelitian ini menggunakan Uji Wilcoxon Signed Rank kemudian menggunakan Uji Perbedaan Ratarata $N$-gain (Kruskal Wallis Test). Melalui uji tersebut didapat hasil bahwa ada perbedaan yang signifikan antara hasil pretest dan posttest sehingga pembelajaran pengajuan masalah berbantuan GeoGebra berpengaruh terhadap pemahaman konsep, berpikir kritis dan penalaran adaptif.

\section{Diagram Perbandingan Hasil Kemampuan} Pada Pre-test dan Post-test

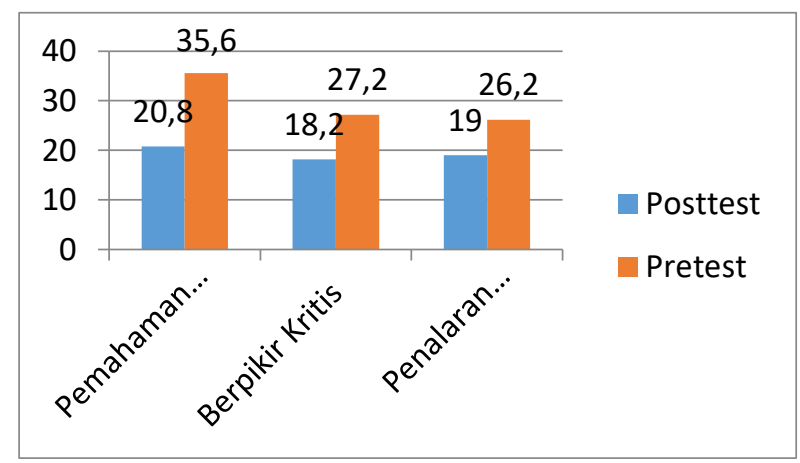

Berdasarkan diagram di atas, hasil rata-rata kemampuan pemahaman konsep, berpikir kritis, dan penalaran adaptif siswa semuanya menunjukkan peningkatan. Dan peningkatan yang paling tinggi terdapat pada kemampuan pemahaman konsep

Tabel 6 Persentase Rata-rata Hasil Observasi Siswa

\begin{tabular}{|c|l|c|}
\hline No & \multicolumn{1}{|c|}{ Aspek Observasi } & Rata - rata \\
\hline 1. & $\begin{array}{l}\text { Mengajukan pendapat kepada } \\
\text { guru/siswa lain }\end{array}$ & $80,71 \%$ \\
\hline 2. & $\begin{array}{l}\text { Merespon pertanyaan / instruksi } \\
\text { guru }\end{array}$ & $80,94 \%$ \\
\hline 3. & $\begin{array}{l}\text { Berdiskusi / partisipasi dalam } \\
\text { kelompok }\end{array}$ & $92,5 \%$ \\
\hline 4. & $\begin{array}{l}\text { Mengerjakan LKS } \\
\text { 5. }\end{array}$ & $\begin{array}{l}\text { Berpartisipasi dalam membuat } \\
\text { soal }\end{array}$ \\
\hline 6. & $\begin{array}{l}\text { Memanfaat sumber belajar yang } \\
\text { ada }\end{array}$ & $85 \%$ \\
\hline
\end{tabular}

Berdasarkan Tabel 2 seluruh aspek yang diamati rata-rata mencapai lebih dari sama dengan $75 \%$ sehingga dapat disimpulkan bahwa aktifitas siswa pada pembelajaran pengajuan masalah berbantuan GeoGebra aktif. Secara umum siswa menikmati dan senang terhadap pembelajaran pengajuan masalah berbantuan GeoGebra.

\section{PENUTUP}

\section{Simpulan}

Berdasarkan hasil penelitian dan diskusi terhadap pengaruh pembelajaran pengajuan masalah berbantuan GeoGebra terhadap pemahaman konsep, berpikir kritis, penalaran adaptif siswa dapat disimpulkan bahwa:

1. Pembelajaran pengajuan masalah berbantuan GeoGebra berpengaruh terhadap pemahaman konsep, berpikir kritis, dan penalaran adaptif.

2. Berdasar pada aktifvitas observasi siswa selama pembelajaran siswa berperan aktif berpartisipasi pada proses pembelajaran dengan baik.

\section{Saran}

Berdasarkan hasil penelitian Pengaruh Pembelajaran Pengajuan Masalah Berbantuan GeoGebra Terhadap Pemahaman Konsep, berpikir Kritis, dan Penalaran Adaptif Siswa, maka peneliti memberikan saran :

1. Untuk memperhatikan alokasi waktu dan menggunakan populasi penelitian yang lebih besar sehingga kesimpulan hasil peningkatan kemampuan siswa diharapkan lebih dapat digeneralisasikan.

2. Dalam hal visualisasi pada software GeoGebra sebaiknya pengajar memberi keterangan dengan 
lebih jelas, seperti memberi catatan dan warna terentu pada visualisasi materi sehingga siswa lebih mudah memahami dan memberi kesempatan siswa untuk mencoba mengoperasikannya (aspek motorik)

3. Hasil penelitian ini diharapkan dapat menjadi ide bagi peneliti lain untuk melakukan penelitian lanjutan yang berpotensi meningkatkan pemahaman konseptual, kemampuan berpikir kritis serta penalaran adaptif siswa dalam pembelajaran matematika.

\section{DAFTAR PUSTAKA}

Akay, H and Boz, N. (2010). The Effect of Problem Posing Oriented Analyses-II Course on the Attitudes toward Mathematics and Mathematics Self-Efficacy of Elementary Prospective Mathematics Teachers. Australian Journal of Teacher Education. 35 (1).59-75

Chance, P. (1986). Thinking in the classroom: A Survey of Programs. New York: Teachers College, Columbia University

Daryanto. (2016). Media Pembelajaran Perannya Sangat Penting Dalam Mencapai Tujuan Pembelajaran. Yogyakarta: Gava Media
Depdiknas. (2006). Permendiknas No 22 Tahun 2006 Tentang Standar Isi. Jakarta: Depdiknas

Iriyanti, Reni (2017). Kemampuan Pemahaman Konsep dan Penalaran Adaptif Pada Siswa SMP yang Diajar melalui Pendekatan Pembelajaran Matematika Realistik Dengan Tipe Structure Dyadic Method. Jakarta: Jurnal Pendidikan Matematika Raflesia

Nila, Kesumawati. (2008). Pemahaman Konsep sMatematika dalam Pembelajaran Matematika

Siswono, T. Y. E. (2000). Pengajuan Soal (Problem Posing) oleh Siswa dalam Pembelajaran Geometri di SLTP. Makalah disajikan pada Seminar Nasional Matematika "Peran Matematika Memasuki Milenium III di ITS Surabaya tanggal 2 Nopember 2000.

Siswono, T. Y. E. (2008). Model Pembelajaran Matematika Berbasis Pengajuan dan Pemecahan Masalah Untuk Meningkatkan Kemampuan Berpikir Kreatif. Surabaya: Unesa University Press.

Siswono, Tatag Yuli Eko. 2017. Penalaran Adaptif dalam Pembelajaran Matematika. Universitas Negeri Surabaya

UNESA. 2000. Pedoman Penulisan Artikel Jurnal, Surabaya: Lembaga Penelitian Universitas Negeri Surabaya 